\title{
BIODEGRADASI LIMBAH TANDAN KOSONG KELAPA SAWIT (Elaeis guineensis Jacq.) MENGGUNAKAN KONSORSIUM BAKTERI PENGHASIL ENZIM SELULASE
}

\section{Biodegradation of Oil Palm Empty Fruit Brunch Waste Using a Microbial Consortium Cellulose Enzyme Activity}

\author{
Ina Darliana \\ Fakultas Kehutanan Universitas Winaya Mukti; Jl. Raya Bandung-Sumedang \\ Km.29 Tanjungsari-Sumedang 45362, (022)87918051 \\ Email:inadarliana2@gmail.com
}

\section{Diterima 8 April 2020/Disetujui 12 April 2020}

\begin{abstract}
This research was conducted to observe the microbial consortium cellulose enzyme activity of oil palm empty fruit brunch. The use of bacterial isolates derived from oil palm empty fruit bunch waste is expected to have a good effect, because the bacteria have been adapted to live in a waste environment that has a high concentration of organic matter. The purpose of this study was to determine the activity of consortium cellulose enzyme activity of bacteria from palm oil waste in the process of biodegradation of oil palm empty fruit bunch waste (Elaeis guineensis Jacq.). The method used is descriptive method. The oil palm empty fruit bunch substrate was fermented and then cellulose enzyme activity was tested using the Somogyi-Nelson method. Doses of bacterial inoculums used in this study were $5 \%$ and $10 \%$. The results showed that the consortium of bacteria from oil palm empty fruit bunch waste at a concentration of $5 \%$ with a value of 4.58 units $/ \mathrm{ml}$ on day 21 had the highest cellulose enzyme activity.
\end{abstract}

Keywords: Enzyme activity, cellulose, Bacteria Consortium, oil palm empty fruit bunches.

\section{PENDAHULUAN}

Tandan kosong kelapa sawit (TKKS) merupakan salah satu jenis limbah padat yang dihasilkan dalam industri minyak sawit. Jumlah TKKS ini cukup besar karena hampir sama dengan jumlah produksi minyak sawit mentah. Limbah tersebut belum 
banyak dimanfaatkan secara optimal. Hal ini disebabkan karena TKKS merupakan bahan organik kompleks yang komponen penyusunnya adalah material lignoselulosa yang kaya unsur karbon. (Sheil et al., 2009).

Biodegradasi merupakan proses dekomposisi bahan organik kompleks yang dilakukan oleh mikroorganisme sehingga menjadi bahan organik sederhana yang kemudian mengalami mineralisasi sehingga menjadi tersedia dalam bentuk mineral yang dapat diserap oleh tanaman (Octavia. 2010). Bakteri adalah mikroorganisme yang berperan penting sebagai pengurai dalam ekosistem. Bakteri mampu beradaptasi terhadap lingkungan dengan konsentrasi kadar limbah tinggi karena mampu mensintesa enzim untuk pertumbuhannya. Eksoenzim yang disekresi bakteri dapat mengurai molekul kompleks menjadi lebih sederhana. Gabungan dari beberapa jenis mikroorganisme yang bekerjasama atau disebut dengan konsorsium biasanya lebih efektif dalam menurunkan beban kadar pencemar bila dibandingkan dengan satu jenis mikroorganisme. Umumnya proses degradasi di lingkungan dilakukan oleh konsorsium mikroorganisme bukan satu jenis saja (Thompson et al., 2005).

Bakteri merupakan agen biologi penting yang mempunyai kemampuan dalam biodegradasi limbah. Kemampuan adaptasi bakteri yang tinggi memungkinkan untuk tumbuh pada substrat dan lingkungan yang tidak mendukung bagi pertumbuhan organisme lain (Anindyawati, 2009). Menurut Wardani, 2011, bakteri selulolitik akan mengeluarkan enzim selulase untuk mendegradasi selulosa menjadi senyawa $\mathrm{C}$ sederhana agar memperoleh energi dan sumber karbon. Bakteri selulolitik mempunyai peran terbesar dalam mendegradasi TKKS, karena selulase yang diproduksi merupakan enzim yang berperan dalam proses biokonversi limbahlimbah organik berselulosa yang spesifik memotong ikatan $\beta-1,4$ glikosidik pada selulosa, yaitu melibatkan enzim endoglukanase, eksoglukanase, dan $\beta$-glukosidase (Meryandini et al., 2009).

Isolat bakteri telah berhasil diisolasi dari limbah TKKS, tiga isolat yaitu Bacillus coagulans, Micrococcus sp dan Bacillus circulans merupakan bakteri selulolitik yang mampu tumbuh pada media yang mengandung selulosa. Secara umum aktivitas selulolitik isolat bakteri ditunjukkan dengan kemampuan tumbuh pada media yang mengandung selulosa sebagai satu- satunya sumber karbon untuk pertumbuhannya dan terbentuknya zona bening di sekitar koloni selama inkubasi 48 jam.

Proses degradasi lignin, selulosa, dan hemiselulosa oleh mikroorganisme memerlukan waktu yang cukup lama. Hal tersebut menyebabkan keseluruhan proses dekomposisi TKKS memerlukan waktu yang lama (Afrizal, 2010). Bakteri 
memainkan peranan penting dalam dekomposisi TKKS dengan tingkat degradasi bahan organik yang tinggi yang terjadi dalam dua minggu pertama pengomposan (Wardani, 2011).Kultur bakteri cukup sederhana, tumbuh dengan cepat, dan memiliki waktu generasi yang singkat, dan manfaat lainnya. Dengan demikian, bakteri memiliki potensi penerapan yang baik pada proses biodegradasi TKKS, dan merupakan agen potensial pendegradasi selulosa (Mahajoeno, 2010).

\section{METODE PENELITIAN}

\section{Aktivitas Enzim Selulase (Metode Somogyi-Nelson)}

Aktivitas enzim selulase diukur setiap 6 hari sekali pada proses fermentasi yang berlangung selama 30 hari. Pengukuran aktivitas enzim selulase meliputi:

\section{a. Pembuatan Kurva Standar Glukosa}

Pembuatan kurva standar glukosa menggunakan aquades sebanyak $1 \mathrm{ml}$ dimasukkan ke dalam tabung reaksi kosong dan 5 tabung reaksi kosong lainnya diisi dengan $1 \mathrm{ml}$ larutan glukosa (0,25-1,5 mg/ml). Lalu, $1 \mathrm{ml}$ larutan DNS (Asam 3,5-dinitrosalisilat) dan $2 \mathrm{ml}$ aquades ditambahkan pada tiap tabung reaksi menggunakan pipet. Semua tabung reaksi dipanaskan di dalam penangas air selama 5 menit agar terjadi reaksi antara glukosa dengan DNS. Kemudian, tabung reaksi didinginkan dan ditambah dengan aquades hingga volumenya menjadi $10 \mathrm{ml}$. Absorbansi tiap larutan diukur dengan panjang gelombang 400, 450, 500, 550, dan $600 \lambda$. Dosis glukosa standar ditunjukkan dengan kurva standar. Cara penghitungan kadar gula pereduksi adalah dengan memasukkan nilai absorbansi pada rumus persamaan linear. Persamaan ini terbentuk pada pembuatan kurva glukosa standar.

\section{b. Pengukuran Kadar Gula Pereduksi (Metode DNS)}

Pengukuran kadar gula pereduksi dilakukan dengan sampel diambil setiap 72 jam selama 30 hari ketika fermentasi berlangsung. Metode yang digunakan untuk mengukur dosis gula pereduksi adalah metode DNS. Sampel diambil sebanyak 2 gram dan diberi $6 \mathrm{ml}$ aquades, lalu dimasukkan ke dalam tabung sentrifugasi. Sampel disentrifugasi dengan kecepatan 3500 rpm selama 20 menit dan supernatant hasil sentrifugasi diambil sebanyak $1 \mathrm{ml}$ dan dimasukkan ke dalam tabung reaksi. Setelah itu ditambahkan $3 \mathrm{ml}$ pereaksi DNS, dihomogenkan dengan vorteks, dan dipanaskan pada penangas air $100^{\circ} \mathrm{C}$ selama lima menit. Selanjutnya didinginkandan diukur dosis gula pereduksi dengan cara dibaca absorbansinya menggunakan spektrofotometer pada panjang gelombang $550 \mathrm{~nm}$. 
Untuk persiapan blanko, aquades sebanyak $1 \mathrm{ml}$ dimasukkan ke dalam tabung reaksi. Kemudian ke dalam tabung reaksi ditambahkan 3 ml larutan DNS. Setelah itu dihomogenkan dengan vorteks dan dipanaskan dalam penangas air mendidih selama 5 menit. Setelah lima menit dipanaskan, kemudian didinginkan.

\section{HASIL DAN PEMBAHASAN}

\section{Pembuatan Kurva Standar Glukosa}

Absorbansi dan konsentrasi memiliki korelasi yaitu absorbansi akan berbanding lurus dengan konsentrasi, artinya konsentrasi semakin tinggi maka absorbansi yang dihasilkan makin tinggi, begitupun sebaliknya konsentrasi makin rendah absorbansi yang dihasilkan semakin rendah. Meningkatnya gula pereduksi akibat aktivitas enzim selulase menunjukkan adanya pemecahan senyawa selulosa, sehingga kadar selulosa akan menurun seiring dengan peningkatan aktivitas enzim selulase (Ismail, 2011).

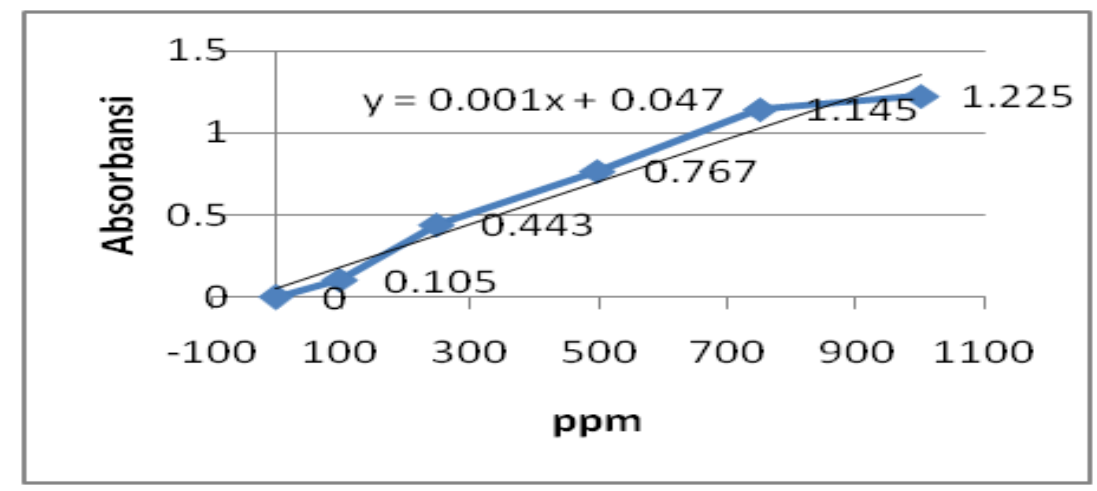

Gambar 1. Kurva Standar Glukosa

\section{Pengukuran Kadar Gula Pereduksi.}

Aktivitas enzim selulase bakeri Bacillus circulans yang tertinggi yaitu sebesar 3.43 unit/ml pada dosis 5\% di hari ke- 21 seperti yang dapat dilihat pada Gambar 2 Aktivitas enzim selulase bakeri Micrococcus sp. yang tertinggi yaitu sebesar 3.21 unit $/ \mathrm{ml}$ pada dosis $10 \%$ di hari ke- 21 seperti yang dapat dilihat pada Gambar 3 Aktivitas enzim selulase bakeri Bacillus coagulans yang tertinggi yaitu sebesar 4.09 unit/ml pada dosis 5\% di hari ke- 21 seperti yang dapat dilihat pada Gambar 4 Aktivitas enzim selulase dari konsorsium bakteri Bacillus coagulans, Micrococcus sp., dan Bacillus circulans merupakan yang tertinggi yaitu sebesar 4.58 unit/ml pada dosis $5 \%$ di hari ke- 21 seperti yang dapat dilihat pada Gambar 5. 
Pada Gambar 2, Gambar 3, Gambar 4 dan Gambar 5 terlihat bahwa aktivitas enzim selulase pada hari ke-0 tinggi seiring dengan pertumbuhan selnya. Namun ketika sel mencapai fase stasioner, aktivitas enzim selulase menurun. Pada fase stasioner kecepatan pembelahan sel sama dengan kecepatan kematian sel dan lisis sel. Selain itu, penurunan aktivitas enzim selulase ini disebabkan karena adaptasi dari bakteri itu sendiri untuk hidup dan berkembang dalam substrat tandan kosong kealap sawit tersebut. Hal ini menyebabkan turunnya aktivitas enzm selulase.

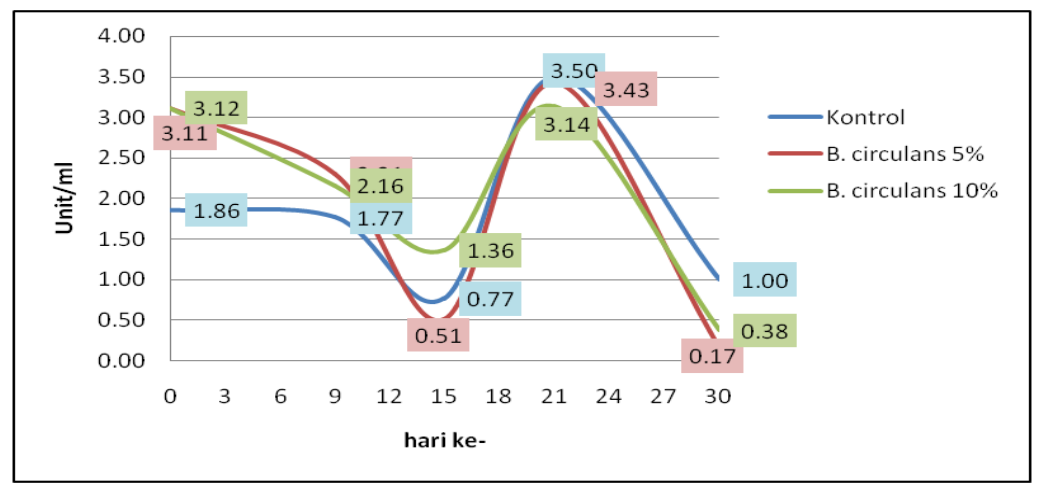

Gambar 2. Aktivitas Enzim Selulase Bakteri Bacillus circulans

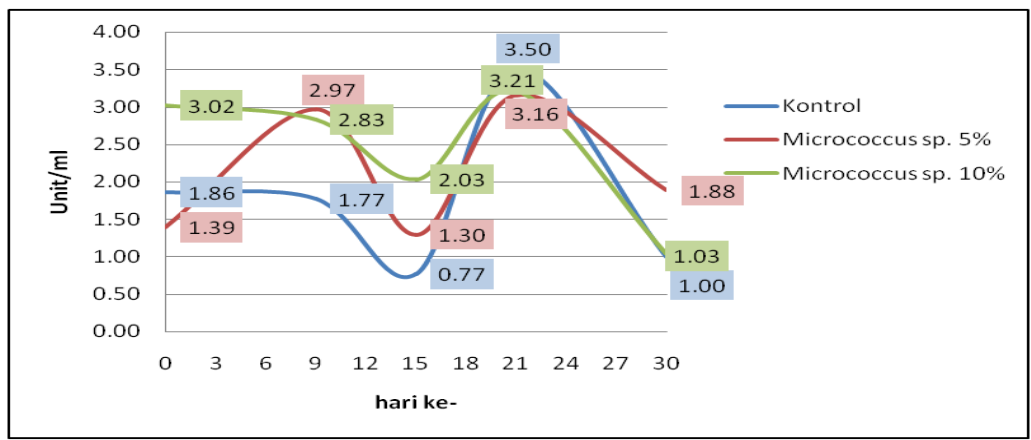

Gambar 3. Aktivitas Enzim Selulase Bakteri Micrococcus sp.

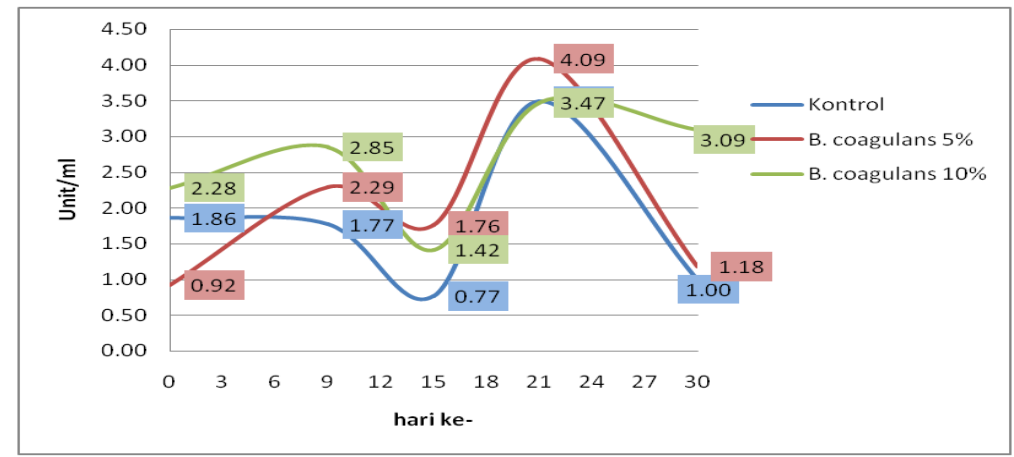

Gambar 4. Aktivitas Enzim Selulase Bakteri Bacillus coagulans 


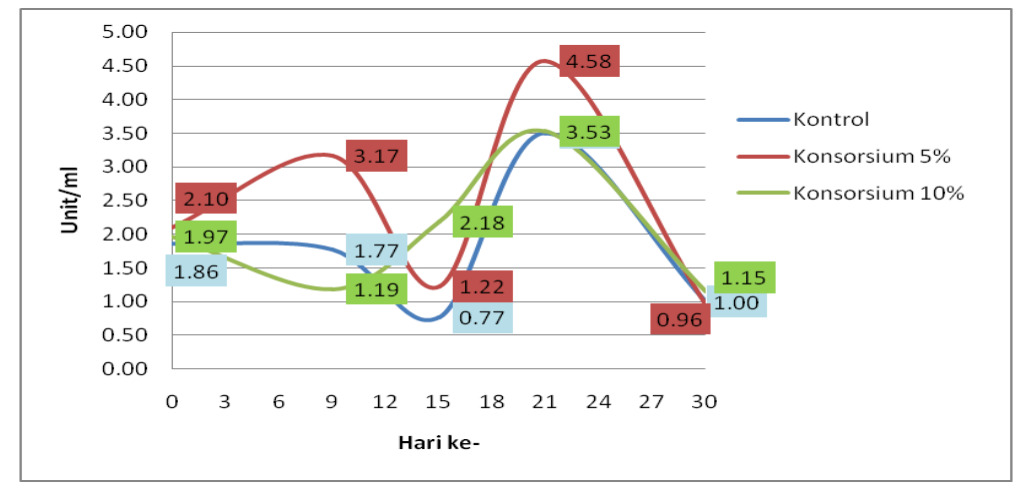

Gambar 5. Aktivitas Enzim Selulase Konsorsium

Selanjutnya aktivitas enzim selulase meningkat kembali hingga mencampai pada puncak tertinggi dalam aktivitasnya pada hari ke-21. Hal ini saling berkaitan karena struktur tandan kosong kelapa sawit terluar adalah komponen lignin yang berfungsi untuk memperkokoh. Sedangkan komponen selulosa berada pada lapisan yang berikatan dengan lignin. Maka diperlukan perombakan komponen lignin terlebih dahulu sebelum perombakan selulosa. Sehingga didapatkan aktivitas enzim selulase tertinggi baru pada hari ke-21. Tingginya aktivitas enzim selulase pada hari ke- 21 ini menandakan waktu optimum bakteri Bacillus coagulans, Micrococcus sp., Bacillus circulans dan konsorsium dalam mendegradasi selulosa. Setelah hari ke-21, aktivitas enzim selulse ini mengalami penurunan kembali. Hal ini disebabkan karena bakteri tersebut sudah tidak mampu lagi beradaptasi dengan lingkungannya serta adanya kompetisi antar bakteri itu sendiri dalam mendapatkan nutrisi-nutrisi penting serta bakteri - bakteri tersebut menggunakan kembali gula yang dihasilkannya sendiri untuk mempertahankan kehidupannya, yang pada ahirnya bakteri ini masuk ke dalam fase kematian, dimana jumlah sel yang mati lebih banyak dari sel yang hidup serta zat - zat metabolit yang dihasilkan oleh bakteri tersebut kemudian menyebabkan kematian bagi bakteri itu sendiri.

Kurva perbandingan akivitas enzim selulase yang dihasilkan oleh bakteri Bacillus coagulans, Micrococcus sp., Bacillus circulans dan Konsorsium pada dosis 5\% dapat dilihat pada Gambar 6 dan pada dosis $10 \%$ dapat dilihat pada Gambar 7.

Berdasarkan kedua kurva (Gambar 6 dan Gambar 7) dapat dilihat bahwa aktivitas enzim selulase yang tertinggi dimiliki oleh konsorsium bakteri Bacillus coagulans, Micrococcus sp., dan Bacillus circulans dengan pemberian dosis 5\% di hari ke- 21. Seperti yang telah disebutkan sebelumnya bahwa struktur tandan kosong kelapa sawit terluar adalah komponen lignin yang berfungsi untuk memperkokoh. Sedangkan komponen selulosa berada pada lapisan yang berikatan dengan lignin. Maka diperlukan perombakan komponen lignin terlebih dahulu 
sebelum perombakan selulosa sehingga dibutuhkan waktu yang lebih lama untuk merombak selulosa. Pemberian dosis 5\% memiliki hasil lebih tinggi dari dosis $10 \%$. Hal ini disebabkan oleh persaingan yang terjadi antara individu bakteri tersebut pada dosis $10 \%$ karena jumlah bakteri yang lebih banyak dibandingkan dengan inokulum dosis 5\% sehingga pemberian inokulum dengan dosis 5\% menjadi dosis optimal bagi konsorsium bakteri Bacillus coagulans, Micrococcus sp., dan Bacillus circulans tersebut dalam mendegradasi selulosa. Konsorsium bakteri Bacillus coagulans, Micrococcus sp., dan Bacillus circulans memiliki aktivitas enzim selulase paling tinggi dikarenakan adanya kerjasama yang sinergis dari ketiga bakteri tersebut yang saling mendukung satu sama lainnya sehingga aktivitas enzim selulase yang dihasilkan lebih tinggi jika dibandingkan dengan bakteri-bakteri ketika bekerja sendiri (tunggal).

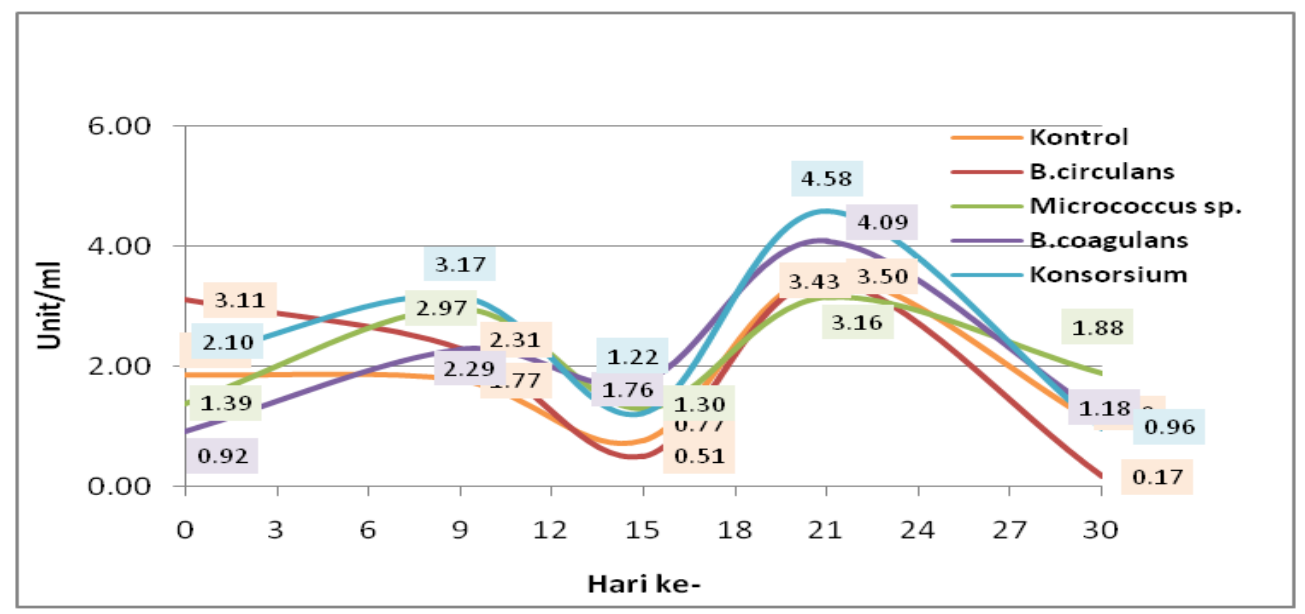

Gambar 6. Aktivitas Enzim Selulase Bakteri bakteri Bacillus coagulans, Micrococcus sp., dan Bacillus circulans pada Dosis 5\%

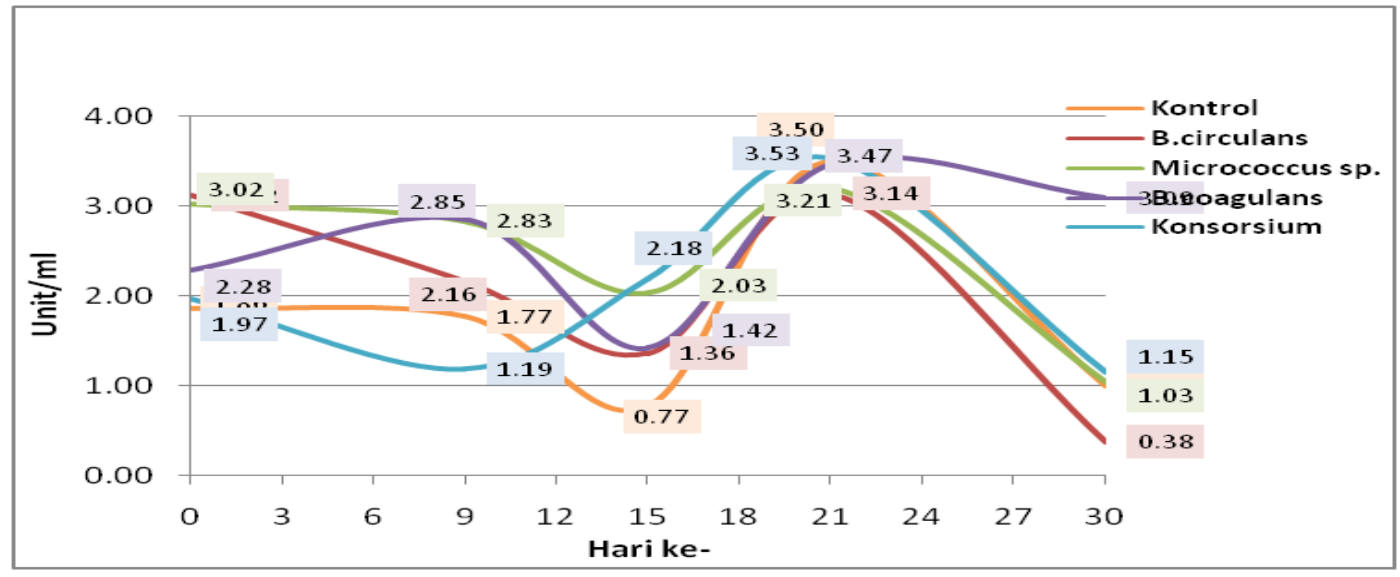


Gambar 7. Aktivitas Enzim Selulase Bakteri bakteri Bacillus coagulans, Micrococcus sp., dan Bacillus circulans pada Dosis $10 \%$

Meningkatnya gula pereduksi akibat aktivitas enzim selulase menunjukkan adanya pemecahan senyawa selulosa, sehingga kadar selulosa akan menurun seiring dengan peningkatan aktivitas enzim selulase (Ismail, 2011). Pada hari selanjutnya terlihat aktivitas enzim selulase B.circulans menurun disebabkan karena bakteri tersebut kembali menggunakan gula yang dihasilkan untuk pertumbuhan (Gunandya dan Antara, 1997). Hays (2004) menambahkan bahwa hampir semua produk glukosa yang dihasilkan akan digunakan oleh mikroorganisme untuk pertumbuhan dan pembelahan sel.

Menurut Irawadi (1999), selulase terdiri dari endoglukanase (CMC-ase), eksoglukanase (selobio-hidrolase), dan $\beta$-glukosidase. Selulase berfungsi sebagai katalisator hidrolisis enzimatis selulosa menjadi glukosa (Ali dan Sastramiharja, 1983). Enzim yang dihasilkan mempunyai kelebihan untuk dikembangkan karena bakteri dapat tumbuh cepat. Enzim tersebut dapat digunakan untuk skala industri, karena jumlahnya tidak terbatas (Rahmadanil, 1994).

\section{SIMPULAN}

Kesimpulan yang yang didapat dari penelitian ini adalah:

1. Jenis perlakuan yang menghasilkan aktivitas tertinggi selama proses biodegradasi Tandan Kosong Kelapa Sawtit (TKKS) adalah konsorsium dari bakteri Bacillus circulans, Micrococcus sp. dan Bacillus coagulans pada dosis $5 \%$ dengan nilai 4.58 unit $/ \mathrm{ml}$.

2. Aktivitas enzim selulase tertinggi didapat pada hari ke-21.

\section{DAFTAR PUSTAKA}

Afrizal, Y. (2010). Industri Kelapa Sawit Sebagai Salah Satu Penghasil Bioetanol. Universitas Sumatera Utara. Medan Retrieved from 20 Januari 2020 from http://repository.usu.ac.id/ bitstream/.

Ali, A. Dan I. Sastramiharja. (1983). Produksi dan Purifikasi Enzim Selulase dari Penicillium vermiculatum 9AA1 Sebagai Hasil Isolasi Jamur-jamur 
Penghasil Selulase dari Tanah Gambut Rantau Rasau Jambi. Bandung: Mikrobiologi Institut Teknologi Bandung.

Anindyawati, T. (2009). Prospek Enzim dan Limbah Lignoselulosa untuk Produksi Bioetanol. Cibinong:Pusat Penelitian Bioteknologi-LIPI.

Irawadi, T.T. (1999). Produksi Enzim Ekstraseluler (Selulase dan Xilanase) dari Neurospora sp pada Substrat Limbah Padat Kelapa Sawit. Bogor: IPB.

Ismail, M. (2011). Pemanfaatan Konsorsium Mikroba Selulolitik Terhadap Penurunan Kadar Selulosa, Hemiselulosa, Lignin, dan Asam Sianida pada Kulit Umbi Singkong. Jatinangor: Universitas Padjadjaran.

Mahajoeno, E. (2010). Limbah Pabrik Kelapa Sawit Dibuat untuk Energi Terbarukan. Retrieved from 20 Januari 2020 from http://www.alpensteel.com/article/53-101-energi-terbarukan renewableenergy/3076.

Meryandini, Wahyu, Besty, Titi, Nisa, dan Hasrul. (2009). Isolasi Bakteri Selulolitik dan Karakterisasi Enzimnya."', .Makara Sains.

Octavia, B. (2010). Kajian Kekayaan Bakteri Indigenous Indonesia untuk Bioremediasi Limbah. Jurusan Pendidikan Biologi FMIPA Universitas Negeri Yogyakarta

Rahmadanil. (1994). Penggunaan Limbah Batang Pisang Sebagai Substrat oleh Tricoderma virirde Pers T04 dan penicillium vermiculatum dangeard 9AA1. Tesis. ITB, Bandung.

Sheil D, Casson A, Meijaard E, van Nordwijk M,Gaskell J, Sunderland-Groves J, Wertz K, \& Kanninen M. (2009). The impacts andopportunities of oil palm in Southeast Asia:What do we know and what do we needto know? Occasional paper no. 51. Bogor: CIFOR.

Swisher, R. D. (1987). Surfactant Biodegradation. Retrieved from 20 Januari 2020 from http://www.lasinfo.org /las _ environment.html.

Thompson, I. P., Gast, C. J. V. D., Ciric, L, \& Singer, A. C. (2005). Bioaugmentation for bioremediation the challenge of strain selection. Envi. Microbiology.

Wardani, S.A. 2011. Isolation and Identification of Aerobic Protein Degrading Bacteria from the Temporary Garbage Disposal Benteng Surabaya. Retrieved from 20 januari 2020 from http://digilib.its.ac.id/ITSUndergraduate-. 